Kuprina O. G.

\title{
CONTROL IN THE PROCESS OF FOREIGN LANGUAGES DISTANCE TRAINING IN A NON-LINGUISTIC HIGHER EDUCATION INSTITUTION
}

Ryazan State Radio Engineering University, 59/1 Gagarin St., Ryazan, 390005, Russian. E-mail: shishkova-olga@yandex.ru

\begin{abstract}
The article covers the issues of learning a foreign language in a non-linguistic higher education institution. The authors show the importance of using the author's distant Moodle-based student courses to increase the efficiency of control in teaching students a foreign language in a nonlinguistic higher education institution. The factors for implementing external feedback (control by the teacher) are proposed: the content of control; control functions; types of control; control methods; forms of control. The specifics of the content of control are revealed. The functions of control (verifying, teaching, developing, educational) are stated. The types (preliminary, current, boundary (periodic) and final), methods (written tasks and tests), forms (individual and frontal) of control implemented in the developed distance learning courses for teaching a foreign language in a non-linguistic institution are described. The features of internal feedback (self-control of students) are presented. The advantages of distance learning for foreign languages on the Moodle platform and the main conclusions based on the survey were outlined.
\end{abstract}

Keywords: control; e-learning; a foreign language; a nonlinguistic higher education institution

Куприна О. Г.

КОНТРОЛЬ В ПРОЦЕССЕ ДИСТАНЦИОННОГО ОБУЧЕНИЯ ИНОСТРАННЫМ ЯЗЫКАМ В НЕЯЗЫКОВОМ ВУЗЕ

Рязанский государственный радиотехнический университет, ул. Гагарина, 59/1, г. Рязань, 390005, Россия

E-mail: shishkova-olga@yandex.ru

\begin{abstract}
Аннотация
В статье обоснованы проблемы изучения иностранного языка в неязыковом вузе. Показана актуальность использования авторских дистанционных учебных курсов, размещенных на платформе Moodle, для повышения эффективности контроля обучения студентов иностранному языку в неязыковом вузе. Предложены факторы реализации внешней обратной связи (контроль со стороны преподавателя): содержание контроля; функции контроля; виды контроля; методы контроля; формы контроля. Выявлена специфика содержания контроля. Изложены функции контроля (проверочная, обучающая, развивающая, воспитательная). Описаны виды (предварительный, текущий, рубежный (периодический) и итоговый), методы (письменные задания и тесты), формы (индивидуальный и фронтальный) контроля, реализуемые в разработанных дистанционных учебных курсах обучения иностранному языку в неязыковом вузе. Представлены особенности внутренней обратной связи (самоконтроль студентов). Изложены достоинства дистанционного обучения иностранным языкам на платформе Moodle и основные выводы на основе проведенного анкетирования.
\end{abstract}

Ключевые слова: контроль; дистанционное обучение; иностранный язык; неязыковой вуз.

\section{Introduction}

At present, both foreign language teachers and non-linguistic higher education institution students face a number of issues demanding their urgent solution. Among others, they include the following:

- different levels of foreign language skills of students studying in one group that demands individualization and differentiation;

- classroom lesson hour number reduction in favour of a greater number of independent work hours that requires using some other besides traditional teaching methods with the aim of a more rational use of time given to the students' out-of-class activities.

Using distance learning technologies is of great use in solving these issues.

It should be noted that one of the trends in the modern education system development is the commitment to the use of information communication technologies that is written in the 
concept of the Federal targeted programme of education development for 2016-2020 [13].

According to this document, the application of information technologies, up-to-date teaching forms and methods in the education sphere should be systematic rather than occasionalo that, in its turn, emphasizes the urgent character of creating an effective control system in the process of e-learning foreign languages at a nonlinguistic higher education institution.

The development of distant educational courses is extensively carried out both in Russia [2, 8, 10] and abroad [1, 4, 5, 7, 12, 14].

For instance, the paper of A.V. Andreev, S.V. Andreeva, I.B. Dotsenko is devoted to the practice of Moodle-based e-learning. A. M. Anisimov's and A. Kh. Giltmundinov's papers consider the Moodle-based distant learning system. M.V. Ivkina studies teaching a foreign language in the Moodle system with the use of information computer technologies.

R. Al-Mahrooqi and S. Troudi consider the application of computer technologies for teaching foreign languages in different countries [1]. C.J. Bonk and C.R. Graham's work is devoted to blended learning both in the global perspective and at the local level [4]. In R. Garrison and H. Vaughan's, N. Peachey's, B. Watwood's works there's analyzed the implementation of online and blended courses in the education process $[7,12,14]$.

The analysis of the printed works showed that in the process of distant learning a great application there is found in the Moodle system that offers a wide range of opportunities for the valid support of the distance education process, also for students' progress control.

Moodle is the system of managing the site's contents specially developed for creating online courses by teachers. Such electronic teaching systems are often called learning management systems or virtual educational environments [3,11].

At the Foreign Languages Department of Ryazan State Radio Engineering University, there were developed and used a number of distant educational courses for teaching students foreign languages.

\section{Main part}

Purpose of the paper. The aim of the paper is scientific methodological grounding of the application of the author's Moodle-based distant educational courses for increasing the efficiency of a foreign language teaching control.

The importance of the information support of students' independent work and increasing the efficiency of its control is conditioned by the fact that recently there have been introduced some great changes into the organization of the university academic work, namely there has been redistributed the academic load: the decrease in the number of classroom hours and correspondingly the increase in the students' independent work.

Material and methods of research. We have studied the possibilities of using the Moodle-based distant educational courses to control student's foreign languages skills as exemplified by the English language teaching. One of the most important functions realized by a teacher is the control function as a teacher's task is to check knowledge, competences and skills in the studied subject acquired by students both in and out of class $[6,9]$. For this purpose there were created distant educational courses with the use of different forms, kinds and methods of control.

The control over students' learning and cognitive activity in the developed distant educational courses is directed both at the external feedback (control on the teacher's part) and the internal feedback (students' self-control).

The external feedback is provided by realizing a number of the factors:

1) control contents;

2) control functions;

3) control kinds;

4) control methods;

5) control forms.

Control contents implies that there's to be checked the level of competencies according to the Federal State Education Standards of Higher Education in the given special field as for the studied subject.

Students beginning to work with a distant educational course may read the description of the anticipated results of their study in the subject in the part "Course background information" placed in the introductory unit.

During e-learning of foreign languages by students in non-linguistic higher educational institutions there are realized the following control functions:

1) the testing function showing the results and evaluation of students' study;

2) the educating function coming by means of recollection, consolidation, specification, updating of the acquired knowledge;

3) the developing function consisting in developing the student's personality, his or her cognitive abilities, concentration, memory, thinking, imagination; 
4) the formative function, the essence of which is disciplining students' work, raising the sense of responsibility for one's work, stimulating careful attitude to it.

In literature in pedagogics there are usually singled out the following control kinds on time grounds: preliminary, current, midterm and final.

The preliminary (diagnostic) control during elearning foreign languages is realized by means of "placement tests" allowing to determine the initial level of students' training in order to look up to the permissible difficulty of the suggested educational contents. The analysis of the data of the preliminary control also allows a teacher to make changes in the distant educational courses with a focus on student's foreign language skills.

The current control allows having continuous information about the progress and quality of education material acquisition, make changes in the process of education in a timely manner. The current control in the developed distant education courses is not so much inspection as education because it is connected with the consolidation, revision and analysis of the education material.

The midterm (periodic) control allows determining the quality of students' studying the education material in the given subject. It's carried out in the form of tests during the term or credits at the end of the term for the courses, the final control of which is an examination.

The final control serves to show the final results of the education process in the given subject. It's realized in the form of credits or examinations.

The requirements to the current, midterm and final controls in the distant education courses are stated in "Methodological recommendations on the subject studying" in the introductory unit.

The control methods allow determining the progress in students' learning and cognitive activity as well as the teacher's pedagogical work.

During e-learning English in the developed courses there are used such main control methods as written tasks and tests.

Written tasks include translating professionoriented texts from English into Russian, tasks to the texts in workbooks, tasks to the viewed video clips or listened in texts on the topic of the studied unit, creative tasks (statement commentary, report writing, research doing, and for master students also - writing an essay, a précis of a scientific article, an abstract and a critique to it, a brief report and a presentation in Power Point on the issue of their scientific research).

Each unit of distant education courses includes tests which are a number of standardized tasks on specific material stating the degree of adopting it by students.
We use the following forms of tests:

I. The closed form when a test has a main part and some answers. Here it's necessary to choose the correct answer following the instructions.

Examples:

"Dragging into the text": Replace the italicized words in the sentences taken from the text with their synonyms.

"Choosing the omitted words": Change the words given in brackets for their synonyms. Complete the sentences according to the text using the omitted words.

"Ordering": Rearrange the below given words so as to correspond to their synonyms given above according to their order. Drag the boxes to change their places.

II. The open form. A student him/herself formulates his or her verbal answer.

Example:

Comment on the quotation given below in writing. Express your agreement or disagreement. Provide your reasons.

"Technology is a useful servant but a dangerous master"

III. Matching tasks.

Examples:

Match the words with their synonyms.

Match the following words with their equivalents in Russian.

Match the words to make word combinations.

Match the following definitions with the corresponding terms.

The assessment of a number of tests is made automatically that substantially reduces the time spent by the teacher for check-up and makes assessment impersonal. Besides, the online version of the progress check register allows students to see their progress in mastering the course. Besides, the access to it is organized in such a way that students can see only their grades and don't know about their fellow students' grades.

In distant courses there prevails an individual form of control, though there's also used a frontal form of control, more often for organizational purposes with the help of "News" and organizational forums.

Internal feedback (students' self-control) is realized by means of:

placing in the introductory unit "Methodological recommendations on the subject studying" on the basis of which students route their own individual education trajectory;

- using "News" and organizational forums;

- realizing module-based rating assessment system thanks to which students can see the results of their educational activities and timely correct them. 
While developing rating control there were solved two tasks:

1) as for contents: there were selected topics, units, tasks, defined the level of knowledge acquisition, the degree of mastering and so on;

2) as for activities: there was analyzed each activity kind, stated their levels of acquisition and grades for each level.

The assessed elements and resources of the distant course are presented in table 1.

Example:

Таблииа 1

\section{Оцениваемые элементы дистанционного курса}

Table 1

Assessed elements and resources of a distant course

\begin{tabular}{|c|c|c|c|}
\hline Module № & Assessed elements and resources & Points & Total \\
\hline \multirow{5}{*}{ 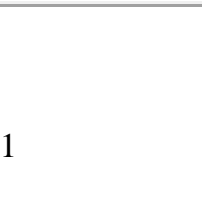 } & Translation of the text "Applications of Electronics" & 5 & \multirow[t]{5}{*}{18} \\
\hline & Workbook on the text "Applications of Electronics" & 2 & \\
\hline & Vocabulary Test 1 & 1 & \\
\hline & Movie Watching "Applications of Power Electronics" & 5 & \\
\hline & Quotation Commentary & 5 & \\
\hline
\end{tabular}

There's also suggested a conversion of points into grades scale (table 2).

Example:

Таблий 2

Шкала перевода баллов в оценки

Table 2

Conversion of points into grades scale

\begin{tabular}{|c|c|c|}
\hline Percentage (\%) & Points & Grades \\
\hline $100-60$ & $240-144$ & Passed \\
\hline $59-0$ & $143-0$ & Not passed \\
\hline
\end{tabular}

Before starting e-learning, students can read all the necessary information about the module-based rating assessment in "Methodological recommendations on the subject studying".

A very useful element of a distant education course is a register. The Moodle system implements a very flexible and rather complex system of assessment on the basis of which as well as on the grounds of students' active work a teacher can create a rating system for each student.

The advantages of the module-based rating system of control in e-learning foreign languages are the following:

- realizing preliminary, current, midterm and final control;

- validity;

- realizing motivation and education functions;

- students' developing self-assessment and self-control skills.

Findings and discussion. Literature analysis and professional experience showed that increasing the control efficiency while developing and implementing Moodle-based distant education courses teaching foreign languages at a non-linguistic higher education institution should be done taking into account their following advantages:

- learning at an individual pace;

- comprehensibility;

- mobility;

- creativity;

- interactivity.

After completing the course of study there was carried out a survey among the students when they were offered to assess the above described advantages of Moodle-based distant education courses teaching foreign languages at a non-linguistic higher education institution using a five-grade scale.

The received results of the survey are given in table 3 .

Таблица 3

\section{Результаты анкетирования студентов}

Table 3

Students' survey results

\begin{tabular}{|l|c|c|c|c|c|}
\hline $\begin{array}{l}\text { Advantages of Moodle-based distant education courses } \\
\text { teaching foreign languages at a non-linguistic higher } \\
\text { education institution }\end{array}$ & 5 & 4 & 3 & 2 & 1 \\
\hline 1. Learning at an individual pace & & 100 & 0 & 0 & 0 \\
\hline 2. Comprehensibility & 95 & 5 & 0 & 0 & 0 \\
\hline 3. Mobility & 70 & 17 & 8,7 & 4,3 & 0 \\
\hline 4. Creativity & 65,2 & 30,4 & 4,4 & 0 & 0 \\
\hline 5. Interactivity & 60,9 & 39,1 & 0 & 0 & 0 \\
\hline
\end{tabular}


As the survey showed, learning at an individual pace (that is, choosing the rate of learning depending on students' individual needs) is an advantage for 100 per cent respondents. The comprehensibility of the organizational, methodological and learning material was graded "five" by 95 percent surveyed students. Mobility was graded "five" by 70 percent respondents, "four" - by 17 percent, "three" - by 8.7 percent, "two" - by 4.3 percent. The individual interview revealed that this advantage got lower grades because of the absence of anytime access to the Internet by some students. As for such an advantage as creativity, 65.2 percent students graded it "five". It's explained by the fact that far from all tasks offered in a distant education course are creative. Some of them are of reproductive and partially research character. Finally, 60.9 percent student graded as "five" interactivity as an advantage of Moodle-based distant education courses teaching foreign languages at a non-linguistic higher education institution. During the individual interview they noted that they would like to intensify the interaction with the teacher to get more detailed consultations.

\section{Conclusion}

On the basis of the presented material it should be noted that the creation of Moodle-based distant education courses is up-to-date and perspective both for the organization of the process of learning foreign languages at a non-linguistic higher education institution and for managing it. In particular, increasing the quality of control in e-learning a foreign language at a non-linguistic higher education institution allows not only to increase the efficiency of education but also to inspire students to further independent studying a second language.

\section{References}

1. Al-Mahrooqi R., Troudi S. (Eds.) Using technology in foreign language teaching. Cambridge Scholars Publishing, 2014. 24 p.

2. Andreev A.V., Andreeva S.V., Dotsenko I.B. The Experience of e-learning with the use of MOODLE. Taganrog: TTI SFEDU, 2008. 146 p. (In Russian).
3. Anisimov A.M. Work in the Moodle-based Elearning System. Kharkov: KhNUUE, 2009. 292 p.

4. Bonk C.J., Graham C.R. (Eds.). Handbook of blended learning: Global perspective, local designs. San Francisco, CA: Pfeiffer Publishing. 32 p.

5. Cahill J.L. Implementing online or hybrid courses in a traditional university. Elearning Papers, 24, 2011. URL: http://elearningpapers.eu/en/article/Implementingonline-or-hybrid-courses-in-a-traditional-university (date of access: April 12, 2017).

6. Egorov V.V., Skibitsky E.G., Khrapchenkov V.G. University pedagogy. Novosibirsk: SAFBD, 2008. 260 p. (In Russian).

7. Garrison R., Vaughan H. Blended learning in higher education: Framework, principles and guidelines. New York: John Wiley \& Sons. 272 p.

8. Giltmundinov A.Kh. Moodle-based e-learning. Kazan: KFU, 2008. 169 p. (In Russian).

9. Gulidov I.N. Teacher's control and its maintenance. M: FORUM, 2005. 240 p. (In Russian).

10. Ivkina M.V. Teaching a foreign language in MOODLE system with the use of information computer technologies. Samara: SGAU, 2012. 68 p. (In Russian).

11. Moodle - e-learning system. URL: www.opentechnology.ru/products/moodle (Retrieved April 19,2017).

12. Peachey N. Web 2.0 tools for teachers. 2012. 53 p. URL: http://technogogy.org.uk/Web20-Tools-forTeachers.pdf (date of access: April 12, 2017).

13. The concept of the Federal targeted programme of education development for 2016 - 2020. URL: http://government.ru/media/files/mlorxfXbbCk.pdf (Retrieved April 19, 2017).

14. Watwood B. Building from content to community: Rethinking the transition to online teaching and learning: A CTE White Paper. Virginia Commonwealth University: Center for teaching excellence, 2009. $22 \mathrm{p}$.

Данные автора:

Куприна Ольга Геннадьевна, доцент кафедры иностранных языков, кандидат педагогических наук, доцент

About the author:

Kuprina Olga Gennadyevna, Associate Professor, Department of Foreign Languages, PhD in Pedagogy, Associate Professor 